\title{
The Impact of Financial Inclusion on Poverty Reduction in Tanzania: Evidence from Mbozi District
}

\author{
Hasunga Japhet Ngailonga ${ }^{1} \quad$ Zawadi Ally $^{2} \quad$ Don Prasad $^{3}$ \\ Aldersgate College, Graduate School, Philippines
}

\begin{abstract}
The study assessed the impact of financial inclusion on poverty reduction among rural people in Tanzania; the sample of 541 was drawn from Mbozi distinct. The study used multiple regression analysis to analyse the data, poverty reduction was assessed in terms of increase in consumption expenditure and household income as outcomes of credit acquisition from financial organs. The findings showed a positive correlation between access to financial services and increase in consumption expenditure as a factor in poverty reduction. It concludes that, among other factors, consumption expenditure would be an appropriate measure upon judging and monitoring the poverty levels among rural households in Mbozi District. The policy implication is that microfinance organs should not turn to hard terms that can prevent that rural household from accessing services.
\end{abstract}

Keywords: financial inclusion, financial institutions, financial services, and poverty

DOI: $10.7176 / \mathrm{EJBM} / 12-25-09$

Publication date:September $30^{\text {th }} 2020$

\section{Introduction}

Access to finance is widely seen as the major binding constraint on growth and consequently on poverty reduction efforts. In view of this, efforts to fight against poverty have been instituted, mainly through country specific policy and international bodies' interventions such as the current United Nations' Sustainable Development Goals (SDGs) (UN, 2016). Most of the governments have adopted SGDs to eradicate extreme poverty in an integrated and comprehensive manner, (UN-, 2016). The SDG's report shows that one in eight people still live in extreme poverty, nearly $800 \mathrm{~m}$ people suffer from hunger, the births of nearly a quarter of children under 5 had not been recorded, 1.1 billion people are living without electricity and water scarcity affects more than 2 billion people. In this case all the nations in the world need to build sustainable development Goals into their national policies and plans. The UN report further indicates that the area which is highly affected is the Sub-Saharan Africa whereby the proportion of people living below $\$ 1.25$ is 48 percent followed by Southern Asia (30 percent) and Southern Asia excluding India (22 percent). In addition, vulnerable employment accounts for 56 percent of all the employment in developing regions, compared to 10 percent in developed regions (UNCTD Report, 2014; UN, 2016). In East Africa, SDGs are reflected through country's specific economic growth strategies. In Kenya, for example, SDGs are implemented through the Kenya's Economic Recovery strategy of 2003 and vision 2030, while in Tanzania; it is through the Development Vision 2025 and the National Strategy for Growth and Poverty Reduction (URT, 2014; Aduda and Kalunda, 2012).

The objective of this study is to assess the impact of financial inclusion on poverty reduction among rural people in Tanzania. The main theme of this study is to understand potentials of financial Inclusion on poverty reduction in rural area in Tanzania, and to what degree this will help to deepen the knowledge on economic policies designed to encourage financial inclusion in Tanzania. The overall argument behind this study is that, the concept of financial inclusion which is increasing gaining popularity in the world in many financial and poverty policy debates not just it brings people in using financial services but also to choose among the availability of options such as payment credit and insurance (Bergess and Pande, 2005) who researched the relationship among the financial inclusion and poverty found that the spread in rural bank branches was more likely to lead in reduction of poverty incidences.

In spite of its importance, the role of financial inclusion has received little empirical attention in Tanzania particularly on its effect on reduction of poverty. Most previous studies have focused on the effect of microfinance programmes on welfare of households, job creation, and women empowerment (Rooyen 2012). In the developed and developing economies some evidence has been documented on the relationship between financial inclusion and poverty reduction (Aportela 1999: Burges and Pande 2005: Honohan 2007 and Beck, Levine and Levkov 2007). These studies revealed that greater financial access reduces poverty however such a relationship is yet to be established in Tanzania. To the best of our knowledge; no study has yet accessed the effect of financial inclusion on poverty reduction in Tanzania using this dataset.

Therefore this study is the first to examine the effect of financial inclusion on poverty reduction in Tanzania using the dataset of Mbozi district. The results of the study will add to the limited existing empirical literature and will provide policymakers with more insights on how financial inclusion and poverty reduction are related.

The rest of the paper is organized as follows: Section 2 presents discusses the theoretical and empirical literature. Section 3 discusses the methodology and data sources. Section 4 reports and discusses results and 
Section 5 draws conclusions and makes policy implications

\section{Literature review}

\subsection{Theoretical background}

From the definition of financial inclusion by the Rangarajan Committee (2008), financial inclusion can be summarized to be the process by which financial services (credit inclusive) are made available to people within the economic system that are not privileged to these services due to low income and inaccessibility in a timely and cost-effective manner. Mohan (2006) also described the concept of financial inclusion as a situation where certain segment of the populace access who hitherto lacked access to the financial system are gradually integrated into it through the provision of low - cost, safe and fair financial products and services from mainstream providers. Ajide (2014) describes financial inclusion as the process of delivering the financial system of a country to its people. Sarma (2012) in her own study described it as the process of ensuring easy access, affordable and convenient use of formal financial services. Aduda and Kalunda (2012) also regarded financial inclusion as the process service provider adopt in making available various financial services, at an affordable price, in a timely manner and accessible to all the members of the society. Financial inclusion is a process, which means it is an ongoing activity. It is obvious that all literatures although might describe it differently but have all agreed that financial inclusion is the effort being made in on boarding people on to the financial system by making financial services available to all especially the low income and rural dwellers. Leeladhar (2006) summarized financial inclusion as the process of delivering to low income and disadvantaged groups banking services at an in a timely and affordably way. However there is no exact theory that explains financial inclusion and poverty reduction nexus in the literature. However, Studies such as Schumpeter (1911), Goldsmith (1969), McKinnon (1973) and Shaw (1973) have all stressed on the importance of financial development on growth as well as poverty reduction. They argue that a well-functioning financial sector if it is properly developed could lead to economic growth and financial development. For instance, through efficient financial intermediation a conducive environment is created which brings lenders and borrowers of funds together and thereby reduces the search and the transaction cost associated with finance. Schumpeter (1911) forcefully argues that well-functioning financial intermediaries promote technological innovation from unproductive to productive sectors by identifying and funding those entrepreneurs with the best chances of successfully implementing innovative products and production processes. He further states that the financial intermediaries play five key roles namely mobilizing savings, evaluating projects, managing risk, monitoring managers and facilitating transactions. Schumpeter's work has been supported by King and Levine (1993) in their work Finance and Growth, Schumpeter Might be Rightll. The authors find that higher levels of financial development are positively associated with faster rates of economic growth, physical capital accumulation and economic efficiency improvements. They stress that the predetermined component of financial development is a good predictor of long-run growth over the next 10 to 30 years. Their results support Schumpeter (1911) argument on the role of finance in economic growth and innovation. McKinnon (1973) and Shaw (1973), took a neo-liberal stand on the role of money in the development process. The authors argue that financially repressive policies in the form of nominal interest rate ceilings, controlled credit allocation and high reserve requirements were not only inefficient, but also the source of economic instability that reduced the volume of financial savings, the rate of real economic growth and the real size of the financial system relative to the nonfinancial sector in developing countries. Financial repression in this context is defined to entail artificially low deposit and loan rates that give rise to excess demand for loans and to non-price credit rationing (McKinnon, 1973; and Shaw, 1973). The McKinnon-Shaw model advocates for financial liberalization to accelerate economic development and economic growth. They contend that financial liberalization would improve the rate of economic growth through increased efficiency in financial intermediation subject to financial discipline (Acheampong, 2007). This implies that strong and resilient financial liberalization will lead to financial inclusion which could have an effect on poverty reduction. Greenwood and Jovanovich (1990) support the existence of an inverted U-shaped relationship between income inequality and financial development; that is, financial development leads to greater inequality to begin with, but which falls back again as financial development continues. This theory is based on the idea that financial intermediaries provide savers with higher returns and lower risks, but that poor individuals initially cannot afford to make use of these financial intermediaries which results in growing inequality. It is assumed, however, that more and more poor people will be able to afford to use these intermediaries over time, offsetting the initial increase in inequality. Ravallion (1997) tests the growth elasticity argument and inducedgrowth argument and added to theory and empirics. The two arguments he advanced were brought together to examine how initial household income distribution influences progress in reducing poverty. By invoking the Gini index, his results indicate that higher inequality tends to entail a lower rate of poverty reduction at any given positive rate of growth. He sums it up by indicating that initial distribution does not affect how much the poor share in rising average incomes. There is no exact theory that explains financial inclusion and poverty reduction nexus in the literature.

These include theories explaining the relationship between financial inclusion and poverty theories such as 
financial intermediation theory. This study will use the value creation model adopted from the National Financial Inclusion Framework of Tanzania (NFIF, 2018). This modification of sustainable livelihood framework (SLF) which best explains the linkages between financial services provision and poverty at household level.

\subsection{Empirical literature}

The early study evidence (Beck et al. 2007) suggests that financial inclusion reduces poverty and income inequality, such evidence is still in its infancy. A very limited number of empirical studies examine the effect of financial inclusion on poverty reduction. Such as Kumar (2013) assessed the behavior and determinants of financial inclusion in India. The study found that the factory proportion and employee base were considered as the significant variables indicating that income and employment generating schemes lead the public to be more active, aware, interested with regard to banking activities, which contributes towards financial inclusion. Singh and Kodan (2012) analyzed the relationship between financial inclusion and development to identify factors associated with financial inclusion. With the help of Regression he found that per capita and urbanization were significant explorers of financial inclusion while literacy, employment and sex-ratio were not statistically significant explorers/predictors of the financial inclusion. Chithral and Selvam (2013) in their attempt to identify and analyze the determinants of financial Inclusion carried out empirical analysis that revealed that socio-economic factors like income, literacy level and population were found to have significant association with the level of financial inclusion. Further, physical infrastructure for connectivity and information were also significantly associated with financial inclusion. Among the banking variables deposit and credit penetration were found significantly associated with financial inclusion. Finally, credit-deposit ratio and investment ratio were not significantly associated with financial inclusion. Anzoategui, at el (2014) study financial inclusion and the role of the post office, by controlling for both individual and country fixed effects for 60 countries, they document that post offices are relatively more likely than traditional financial institutions, in estimating several probit models for 123 countries for both individual and country specific characteristics, Allen et al., (2014) find that greater ownership and use of accounts is associated with a better enabling environment for accessing financial services such as lower account costs and greater proximity to financial intermediaries. The authors document that policies targeted to promote inclusion such as requiring banks to offer basic or low-fee accounts, exempting some depositors from onerous documentation requirements, allowing correspondent banking, and using bank accounts to make government payments are especially effective among those most likely to be excluded. Finally, the authors study the factors associated with perceived barriers to account ownership among those who are financially excluded and report that these individuals report lower barriers in countries with lower costs of accounts and greater penetration of financial service providers. The weakness of their study is their failure to account for continental or regional dynamics; hence conclusions drawn from it may not be applicable to all. This is because legal or regulatory institutions in these countries or economic zones differ from one another. In examining an overview of financial inclusion in Africa using descriptive statistics Demirgüç-Kunt and Klapper (2012), report that less than a quarter of adults in Africa have an account with a formal financial institution and that many adults in Africa use informal methods to save and borrow. Thus, $23 \%$ of adult Africans have accounts at a formal financial institution and about $77 \%$ remained unbanked (do not have bank account at a formal financial institution). Similarly, they observe that majority of small and medium enterprises in Africa are unbanked and access to finance is a major obstacle. As compared with other developing economies, the authors report that high-growth small and medium enterprises in Africa are less likely to use formal financing, which suggests formal financial systems are not serving the needs of enterprises with growth opportunities. Their study only provides descriptions of the problem without testing for statistical significance. Mondal, (2015) had established the relationship between financial inclusion and poverty alleviation. Lal (2018) and Mubiru (2012) were able to establish a positive relationship between financial inclusion and poverty alleviation. Most of the previous studies are conceptual in nature, and few of them that are tested empirically are small in scope. The nature and extent of effect of Financial Inclusion on poverty alleviation the moderating effect of microfinance remained untouched in the existing literature. From the foregoing literature review one can draw the following conclusions: there is no empirical evidence in Tanzania context on the relationship between financial inclusion and poverty reduction, although a few studies exist in some African countries which focusing on microfinance challenges on income inequality. Thus, there is a considerable gap on the relationship between financial inclusion and poverty reduction in Tanzania.

\section{Methodology}

\subsection{Sample Size}

The study was conducted in Songwe Region where Mbozi district is located. Mbozi district has been strategically selected because it is one among the most important areas where a number of financial institutions have been established to provide financial services to the rural people in the district. In this study, the sampling unit of analysis was the individuals in rural areas in Mbozi district. The sample size for this study was 541, determined based on a formula by Fisher et al. (1991) . Both non-probability and probability sampling procedures were used. The 
sample size formula used was: $\mathrm{n}=\mathrm{Z}^{2} \mathrm{Pq} / \mathrm{d}^{2}$

Where:-

$\mathrm{n}=$ Sample size when population under study is greater than 10,000

$\mathrm{Z}=$ Standard normal deviate (z-score set at 1.645 , corresponding to a confidence interval of $90 \%$ )

$\mathrm{P}=$ Proportion in the target population estimated to have a particular characteristic; if not known use a proportion of 0.5

$\mathrm{q}=$ Is the proportion of the population lacking a particular characteristic of interest

$\mathrm{d}=$ Degree of accuracy (significance level) desired, set at 0.05

Therefore the sample size was calculated as follow::

$$
\begin{aligned}
& \mathrm{n}=\mathrm{Z}^{2} \mathrm{Pq} / \mathrm{d}^{2},=(1.645)^{2}(0.50 .) /(0.05)^{2} \\
& =(2.706025 \times 0.25) / 0.0025 \\
& \mathrm{n}=541
\end{aligned}
$$

\subsection{Model Specification}

Descriptive statistics was used to represent the general demographic picture of respondent who assessed upon the access to financial services in the study area. Under this case, demographic variables considered were gender, age and education level. The output with regard to access to financial services under this case was presented in percentages.

The study used multiple regression analysis to assess the impact of access to financial services on poverty reduction. Poverty reduction was assessed in terms of increase in consumption expenditure and household income as outcomes of credit acquisition from financial organs/institutions. With this concern the following hypotheses were developed;

Expenditure: The null hypothesis $\left(\mathrm{H}_{\mathrm{O}}\right)$ accounted for the access to financial services to have no significant impact on the increase in consumption expenditure. Whereas;

Income: The null hypothesis $\left(\mathrm{H}_{\mathrm{O}}\right)$ accounted for the access to financial services to have no significant impact on the increase in household income.

The two sub-hypothesis were tested following the multiple regression model by the following relations:

$\mathrm{Y}_{\mathrm{e}}=\beta \mathrm{o}+\beta_{1} \mathrm{X}_{1}+\beta_{2} \mathrm{X}_{2}+\mathrm{e}$ (Expenditure)

$Y_{i}=\beta o+\beta_{1} X_{1}+\beta_{2} X_{2}+e($ Income $)$

Where $Y_{e}$ and $Y_{i}$ - are dependent variables measured as the amount of money spent on household consumption and income generated respectively.

$\mathrm{X}_{1}$ and $\mathrm{X}_{2}$ are predictors considered to draw the access to financial services in terms of flexibility to access financial services and ability to repay loan respectively

$\mathrm{e}$ is the error term.

\subsection{Results and Discussion}

\subsection{Demographic Characteristics of Respondents}

Findings show that, over $50 \%$ of households had access to financial services; about $41.8 \%$ had no access. With regard to access males were in large number $(43.9 \%)$ when compared to females $(14.3 \%)$. Based on age those aged above 45 years were less involved in financial services than individuals aged below 45 years. Education impacted mostly those with primary level as $34.2 \%$ of this level had flexibility to access financial services. It can therefore be generalized that, access to financial services favored in most cases males, particularity at the most productive age group of 31 to 45 years. This poses a consideration of gender, particularly in females, though were in small number during the field survey. 
Table 4.1: Demographic variables

\begin{tabular}{lcrr}
\hline Variable & \multicolumn{2}{c}{ Acess to Finance } & Total \\
\cline { 2 - 3 } Gender & Yes & No & \\
Male & & & $72.0 \%$ \\
Female & $43.9 \%$ & $28.0 \%$ & $28.0 \%$ \\
Overall & $14.3 \%$ & $13.7 \%$ & $100.0 \%$ \\
Age & $58.2 \%$ & $41.8 \%$ & $27.0 \%$ \\
16-30 & & & $47.9 \%$ \\
$31-45$ & $17.6 \%$ & $9.4 \%$ & $22.1 \%$ \\
46-60 & $29.4 \%$ & $18.5 \%$ & $3.0 \%$ \\
Above 60 & $10.6 \%$ & $11.5 \%$ & $100.0 \%$ \\
Overall & $.3 \%$ & $2.7 \%$ & $8.4 \%$ \\
Education & $57.9 \%$ & $42.1 \%$ & $61.3 \%$ \\
No formal & & & $16.8 \%$ \\
Primary & $2.7 \%$ & $5.7 \%$ & $9.6 \%$ \\
Secondary/High School & $34.2 \%$ & $27.0 \%$ & $3.9 \%$ \\
College/Vocational & $8.7 \%$ & $8.1 \%$ & $100.0 \%$ \\
Postgraduate/Graduate & $8.4 \%$ & $1.2 \%$ & $0.0 \%$ \\
Overall & $3.9 \%$ & $42.0 \%$ & \\
\hline
\end{tabular}

Source: Authors 2019

\subsection{Poverty reduction and Access to Services}

This section presents the findings used to assess the impact of access to financial services on poverty reduction among rural households in Mbozi District. Based on two sub hypotheses formulated that included increases in household consumption expenditure and increase in income as to study a reduction in poverty, the outputs of regression analysis were discussed based on poverty predictors that were significant.

\subsubsection{Access to financial services and Increase in consumption expenditure}

This hypothesis tested the effect of household's ability to access financial services on the increase in consumption expenditure. Repayment of the loan within a given time and flexibility of a household to access financial services was used as predictors of increase in consumption expenditure in the model.

\subsubsection{Model Summary}

Based on the model summary (Table 4.2), results indicate a positive correlation between access to financial services and increase in consumption expenditure $(r=0.307, p$-value $<0.1)$. The access to financial services was explained by the model to increase by $9.4 \%$ in consumption expenditure (R-Square $=0.94)$. This indicates that an increase in consumption expenditure is partly attributed by chance of a household to access financial services.

Table 4.2: Model Summary

\begin{tabular}{|c|c|c|c|c|c|c|c|c|c|}
\hline \multirow[t]{2}{*}{ Model } & \multirow[t]{2}{*}{$\mathrm{R}$} & \multirow{2}{*}{$\begin{array}{c}\mathrm{R} \\
\text { Square }\end{array}$} & \multirow{2}{*}{$\begin{array}{c}\text { Adjusted R } \\
\text { Square }\end{array}$} & \multirow{2}{*}{$\begin{array}{l}\text { Std. Error of } \\
\text { the Estimate }\end{array}$} & \multicolumn{5}{|c|}{ Change Statistics } \\
\hline & & & & & $\begin{array}{l}\text { R Square } \\
\text { Change }\end{array}$ & $\begin{array}{c}\mathrm{F} \\
\text { Change }\end{array}$ & df1 & $\mathrm{df} 2$ & $\begin{array}{c}\text { Sig. F } \\
\text { Change }\end{array}$ \\
\hline 1 & .307 & .094 & .057 & 206289.78480 & .094 & 2.544 & 2 & 49 & .089 \\
\hline
\end{tabular}

Source: Authors 2019

Predictors: (Constant), Loan repayment, Access to financial services Dependent Variable: Consumption expenditure, Level of significance $=0.1$

\subsubsection{Significance of the Model}

The overall significance to predict to test whether the model was fit to predict the outcome was performed by analysis of variance (ANOVA) using the mean values of expenditures. Results (Table 4.3) indicate that, the overall model was statistically significant at $10 \%$ ( $\mathrm{p}$-value $<0.1, \mathrm{~F}$ ratio $=2.544$ ) to predict an increase in consumption expenditure better. Thus supporting an alternative hypothesis that, access to financial services has significant impact on the increase in consumption expenditure among rural households in Mbozi District

Table 4.3: ANOVA

\begin{tabular}{lccrcc}
\hline Model & Sum of Squares & df & Mean Square & F & Sig. \\
\hline Regression & 216556228835.572 & 2 & 108278114417.786 & 2.544 & .089 \\
Residual & 2085218290395.198 & 49 & 42555475314.188 & & \\
Total & 2301774519230.770 & 51 & & & \\
\hline Source: Auth & & & & &
\end{tabular}

Source: Authors 2019 


\subsubsection{Regression Outputs}

The coefficients for access to financial services on predicting an increase in expenditure were presented in Table 4.4. Results show that, the flexibility of a household to access financial services was statistically significant ( $\mathrm{p}$ value $<0.1)$ to predict poverty reduction in terms of increase in consumption expenditure. Flexibility to access services has positive effects to increase in consumption expenditure with a beta value of 201244.372 for coefficients. The ability of a household to repay the loan was not statistically significant enough to predict poverty reduction in terms of consumption expenditure ( $p$-value $>0.1$ ). Therefore, with regard to consumption expenditure as a poverty reduction indicator, the regression among rural households in the study area adjusts to Y(Expenditure) $=-106,565.783+201,244.372$ Acess, implying that households that were able to access financial services were likely to increase by an average of TAS 201,244.372 in consumption expenses per month for different enterprises and livelihood undertakings. Based on the regression model, each household that had access to financial services would have consumed a significant net amount of TAS 94,678.59. This amount was equivalent to TAS 631.19 per day per capita. Regarding the prevailing national poverty line of USD 1.9 per day per capita, access to financial services would have been said to reduce poverty by $14 \%$.

Table 4.4: Regression coefficients

\begin{tabular}{|c|c|c|c|c|c|c|c|}
\hline \multirow[t]{2}{*}{ Model } & \multicolumn{2}{|c|}{$\begin{array}{l}\text { Unstandardized } \\
\text { Coefficients }\end{array}$} & \multirow{2}{*}{$\begin{array}{c}\text { Standardized } \\
\text { Coefficients } \\
\text { Beta }\end{array}$} & \multirow[t]{2}{*}{$\mathrm{t}$} & \multirow[t]{2}{*}{ Sig. } & \multicolumn{2}{|c|}{$\begin{array}{l}90.0 \% \text { Confidence Interval } \\
\text { for B }\end{array}$} \\
\hline & B & Std. Error & & & & $\begin{array}{l}\text { Lower } \\
\text { Bound }\end{array}$ & $\begin{array}{l}\text { Upper } \\
\text { Bound }\end{array}$ \\
\hline (Constant) & 106565.783 & 184153.176 & & -.579 & .565 & -415307.955 & 202176.389 \\
\hline $\begin{array}{l}\text { Flexibility to access } \\
\text { to financial services }\end{array}$ & 201244.372 & 89645.770 & .306 & 2.245 & .029 & 50948.676 & 351540.069 \\
\hline Loan repayment & -17883.942 & 54201.446 & -.045 & -.330 & .743 & -108755.424 & 72987.540 \\
\hline
\end{tabular}

Source: Authors 2019

Dependent Variable: Consumption Expenditure

\subsection{Access to financial services and Increase in Household Income}

The model summary (Table 4.5), results indicate a positive correlation between access to financial services and increase in household as a measure poverty reduction, however the relation was not statistically significant $(\mathrm{r}=$ 0.285 , $\mathrm{p}$-value $>0.1$ ). This implies that, increase in household income not affected by the ability of a household to access financial services and therefore income was eliminated to assess poverty reduction among rural households in Mbozi District.

Table 4.5: Model summary

\begin{tabular}{|c|c|c|c|c|c|c|c|c|c|}
\hline \multirow[t]{2}{*}{ Model } & \multirow[t]{2}{*}{$\mathrm{R}$} & \multirow{2}{*}{$\begin{array}{c}\mathrm{R} \\
\text { Square }\end{array}$} & \multirow{2}{*}{$\begin{array}{l}\text { Adjusted R } \\
\text { Square }\end{array}$} & \multirow{2}{*}{$\begin{array}{l}\text { Std. Error of } \\
\text { the Estimate }\end{array}$} & \multicolumn{5}{|c|}{ Change Statistics } \\
\hline & & & & & $\begin{array}{c}\text { R Square } \\
\text { Change }\end{array}$ & $\begin{array}{c}\mathrm{F} \\
\text { Change }\end{array}$ & df1 & $\mathrm{df} 2$ & $\begin{array}{l}\text { Sig. F } \\
\text { Change }\end{array}$ \\
\hline 1 & .285 & .081 & .047 & 300491.40815 & .081 & 2.351 & 2 & 53 & .105 \\
\hline
\end{tabular}

Authors 2019

Predictors: (Constant), Loan repayment, Flexibility to access to financial services

Dependent Variable: Income

\subsection{Conclusion}

The study assessed the impact of financial inclusion on poverty reduction among rural people in Tanzania, the evidence from Mbozi district. The main theme of this study is to understand potentials of financial Inclusion on poverty reduction in rural area in Tanzania, and to what degree this will help to deepen the knowledge on economic policies designed to encourage financial inclusion in Tanzania. This study found a positive correlation between access to financial services and increase in consumption expenditure as a factor in poverty reduction among rural households. However, an increase in household income as a measure of poverty reduction was not explained to have been attributed by access to financial services rather might have been contributed by a combination of different enterprises. Although, there was a room to access financial services still, a large percentage of households lived below the national poverty line. This study concludes that, among other factors, consumption expenditure would be an appropriate measure upon judging and monitoring the poverty levels among rural households in Mbozi District.

The policy implication of this study is that, microfinance organs should not turn to hard terms that can prevent that rural household from accessing services, including the magnitude of loan provided. Since consumption contributed partly to poverty reduction, the trend should be further assessed and monitored rationally to savings and investments so as to sustain the financial practices in the study area. 


\section{References}

Acheampong, I. (2007). Testing McKinnon-Shaw thesis in the context of Ghana's financial sector liberalisation episode. International Journal of Management Research and Technology, 1(2), 156-183.

Aduda, J. and Kalunda, E. (2012). Financial Inclusion and Financial Sector Stability with Reference to Kenya: A Review of Literature. Journal of Applied Finance and Banking, Vol 2, No 6(95-120).

Ajide,F.M. (2014), Financial inclusion and rural poverty reduction: Evidence from Nigeria

Allen F, Carletti E, Cull R, Qian JQJ, Senbet L, Valenzuela P (2014) The African financial development and financial inclusion gaps. Journal of African Economies, 23(5):614-642

Anzoategui, D., Demirguc-Kunt, A. and Peria, M.S.M. (2014), Remittances and financial inclusion: evidence from El Salvador, World Development, 54:338-349.

Aportela, F. (1999). 'Effects of financial access on saving by low income people', Research Department, Banco de México, Mexico City

Beck, T., Demirgüç-Kunt, A. and Levine, R. (2007),'Finance, inequality and the poor' Journal of Economic Growth, no. 12, pp. 27-49

Beck, T., Levine, R. and Levkov, A. (2007).'Big bad banks? The impact of U.S. branch deregulation on income distribution'. NBER Working Paper Series No. 13299

Burgess, R. and Pande, R. (2005)'Do rural banks matter? Evidence from the Indian social banking experiment', The American Economic Review, vol. 95, no. 3, pp. 780-795

Demirgüç-Kunt, A. and Klapper, L. (2012) 'Measuring financial inclusion', The Global Findex Database, World Bank Policy Research Working Paper 6025

Goldsmith, R. W. (1969). Financial structure and development (Vol. 1): Yale university press New Haven.

Greenwood, J. and Jovanovic, B. (1990). 'Financial development, growth, and the distribution of income', Journal of Political Economy, vol. 98, no. 5, pp. 1076-1107.

Honohan, P. (2007). 'Cross country variation in household access to financial services'. The World Bank. Trinity College Dublin and CRPR

Kumar, N. (2013), Financial inclusion and its determinants: evidence from India, Journal of Financial Economic Policy, 5(1): 4-19.

Lal T. (2018), Impact of financial inclusion on poverty alleviation through cooperative banks. International Journal of Social Economics, 45(5):808-828.

Leeladhar, V. (2005), =Taking banking services to the common man-Financial inclusion“

McKinnon, R. (1973). Money and Capital Economic Development, Brookings Institutions, Washington D.C

Mohan, R. (2006), Economic growth, financial deepening and financial Inclusion'. A Paper presented at the Annual Bankers' Conference 2006, at Hyderabad on Nov 3, 2006.

Mondal S (2015), Financial Inclusion: a step towards eradicate poverty. American Journal, vol.3, no.4, pp. 150156.

Mubiru J (2012)m Financial Inclusion as tool for Combating Poverty: Joseph Mubiru Memorial Lecture. In Bangladesh Bank,

Olomola, A., (2000). "Determinants of the smallholder loan repayment performance: Evidence from the Nigerian microfinance system"

Rangarajan Committee, (2008), Report of the Committee on Financial Inclusion," Retrieved from https://www.sidbi.in/files/Rangarajan-Commitee-report-on-Financial-Inclusion.pdf

Ravallion, M. (1997). Can high-inequality developing countries escape absolute poverty? Economics Letters, 56(1), 51-57.

Rooyen, V.C. (2012). The impact of microfinance in Sub-Saharan Africa: A systematic review of the evidence'. World Development, vol. 40, no. 11, pp. 2249-2262.

Sarma, M. (2012). Index of Financial Inclusion-A measure of financial sector inclusiveness: Hochschule fuer Technik und Wirtschaft, Berlin.

Schumpeter, J.A. (1911). The Theory of Economic Development, New York: Oxford University Press

Shaw, E. (1973),Financial Deepening in Economic Development. New York: Oxford University Press.

United Nations (UN, 2016). The Sustainable Development Goals Report, UN, New York.

United Nations Conference on Trade and Development (UNCTD) (2014), Impact of Access to Financial Services Including by Highliting Remittances on Development: Economic Empowerment of Women and Youth, UN, New York.

URT (2014), Basic Demographic and Socio-Economic Profile Report, Tanzania Mainland, National Bureau of Statistics, (NBS), Ministry of Finance, DSM 